\title{
PERBEDAAN KADAR INTERLEUKIN-1 $\beta$ SALIVA ANTARA PENDERITA MYOFASCIAL PAIN DENGAN DISC DISPLACEMENT SENDI TEMPOROMANDIBULA
}

\author{
(DIFFERENT LEVEL OF INTERLEUKIN-1 $\beta$ SALIVA IN MYOFACIAL PAIN \\ AND DISC DISPLACEMENT OF TEMPOROMANDIBULAR JOINT)
}

\author{
Elita Rafni*, Yanwirasti**, Eriyati Darwin***, Rasmi Rikmasari***** \\ *Departemen Prostodonsia Rumah Sakit Arifin Achmad, Universitas Riau \\ ***Departemen Patologi Anatomi, \\ Fakultas Kedokteran, Universitas Andalas \\ ****Departemen Patologi Klinik, \\ Fakultas Kedokteran, Universitas Andalas \\ ****Departemen Prostodonsia, \\ Fakultas Kedokteran Gigi, Universitas Padjadjaran \\ E-mail: elita.rafni@gmail.com
}

\begin{abstract}
Temporomandibular joint disorders can occur due to neurogenic inflammation that involves cytokines. In temporomandibular joint disorders patient with pain, it is found algogenic prostaglandin and lukotrien substances as pain dan inflammation mediators. Prostaglandin derived from arachidonic acid that transformed to prostaglandin E2 (PGE2) because of cyclooxygenase-2 (Cox2) activity induced by interleukin 1 beta (IL-1 $\beta$ ) cytokine. Saliva is the type of liquid which contains enzyme, hormone, antibody, constituent microbe, and cytokines that are found in blood. This research was to examine the different level of IL-1 $\beta$ in myofascial pain and disc displacement of temporomandibular joint disorders patients. The method used in this research was cross sectional comparative study with both dependent and independent variables were tested at the same time. The research was done at the Prosthodontics Polyclinic of Arifin Achmad Pekanbaru Hospital and at the Biomedic Laboratory of Faculty of Medicine Andalas University Padang by examining the saliva samples of 37 myofascial pain patients and 37 disc displacement patients. The level of IL-1 $\beta$ examined by the Elisa and the result was analyzed with $t$ test. Kolmogorov Smirnov statistical test found that data normally distributed both for the gender group ( $\mathrm{p}$ value $=0.772$ ), and the age group $\mathrm{p}$ value $=1.000$ ). The average value of IL1- $\beta$ level for all of the data with disc displacement was $0.57 \pm 0.45 \mathrm{~nm} / \mathrm{L}$ and myofascial pain was $0.22 \pm 0.18 \mathrm{~nm} / \mathrm{L}$. From the t-test, there was a significant difference on IL-1 $\beta$ level in saliva between myofascial pain and disc displacement with value $\mathrm{p}=0.00(\mathrm{p}<0.05)$. The conclusion that the level of IL-1 $\beta$ in saliva of patients with disc displacement of temporomandibular joint disorders was higher than patients with myofascial pain.
\end{abstract}

Key words: Temporomandibular joint disorders, myofascial pain, disc displacement

\begin{abstract}
Abstrak
Gangguan sendi temporomandibula dapat terjadi karena peradangan neurogenik yang banyak melibatkan sitokin. Pada penderita gangguan sendi temporomandibula dengan keluhan nyeri ditemukan adanya substansi algogenik prostaglandin dan lukotrien sebagai mediator nyeri dan inflamasi. Prostaglandin berasal dari asam arakidonat yang berubah menjadi PGE2 karena aktivitas Cox2 yang diinduksi oleh sitokin IL-1 $\beta$. Saliva merupakan cairan yang mengandung hormon, antibodi, konstituent mikroba, dan sitokin seperti yang terdapat dalam darah. Penelitian ini dilakukan untuk melihat perbedaan kadar IL-1 $\beta$ pada penderita myofascial pain dan disc displacement sendi temporomandibula. Penelitian ini menggunakan metode cross sectional comparative. Variabel dependen dan independen diperiksa secara bersamaan. Penelitian ini dilakukan di Poliklinik Prostodonsia Rumah Sakit Arifin Ahmad Pekanbaru dan Laboratorium Biomedik Fakultas Kedokteran Universitas Andalas Padang. Pemeriksaan sampel saliva dilakukan pada 37 penderita myofascial pain dan 37 penderita disc displacement. Kadar IL-1 $\beta$ diperiksa dengan Elisa dan data dianalisis dengan $t$ test. Berdasarkan uji statistik Kolmogorov Smirnov ditemukan bahwa data terdistribusi normal baik pada kelompok gender ( $\mathrm{p}$ $=0,772$ ) maupun kelompok umur $(\mathrm{p}=1,000)$. Rerata nilai kadar IL-1 $\beta$ penderita myofascial pain adalah $0,22 \pm 0,18 \mathrm{~nm} / \mathrm{L}$ dan penderita disc displacement adalah $0,57 \pm 0,45 \mathrm{~nm} / \mathrm{L}$. Hasil analisis t-test menunjukkan terdapat perbedaan kadar IL-
\end{abstract}


$1 \beta$ saliva yang signifikan antara penderita myofascial pain dan disc displacement $p=0,01(p<0,05)$. Sebagai kesimpulan bahwa kadar IL-1 $\beta$ lebih tinggi pada disc displacement dibandingkan myofascial pain.

Kata kunci: Gangguan sendi temporomandibular, myofascial pain, disc displacement.

\section{PENDAHULUAN}

Gangguan sendi temporomandibula pada saat ini menunjukkan prevalensi yang meningkat. Di Amerika Serikat, dilaporkan prevalensi gangguan sendi temporomandibula pada orang dewasa sekitar $6-12 \%{ }^{1}$ Di Indonesia, ditemukan bahwa 79\% dari 498 orang dewasa di Jakarta menderita gangguan sendi temporomandibula. ${ }^{2}$ Penelitian Luciana ${ }^{2}$ memperoleh prevalensi tingkat keparahan gangguan sendi temporomandibula berdasarkan jenis kelamin dan kelompok umur sebesar $84,33 \%$ dengan presentase terbanyak 54,48\% mengalami gangguan ringan. Menurut survei yang dilakukan oleh WHO tahun 2002, bahwa 5-12\% po-pulasi penduduk dunia menderita gangguan pada muskuloskeletal dengan keluhan nyeri. ${ }^{4}$ Prevalensi myofascial pain di Amerika pada klinik ortopedi umum sebesar data $21 \%$ mengalami gejala nyeri kepala. ${ }^{4}$

Gangguan sendi temporomandibula dapat terjadi karena peradangan neurogenik yang banyak melibatkan sitokin. Pada penderita gangguan STM dengan keluhan nyeri ditemukan adanya substansi algogenik prostaglandin dan Leukotrien 4 sebagai mediator nyeri dan inflamasi. ${ }^{3}$ Prostaglandin berasal dari asam arakidonat yang berubah menjadi prostaglandin karena aktivitas Cox 2 yang diinduksi oleh sitokin interleukin-1 $\beta$ (IL-1 $\beta$ ), oleh karena itu, manifestasi Prostaglandin dipertahankan oleh Cox2 yang merupakan vasodilator yang menghasilkan nyeri dan inflamasi dan memproduksi matrix metalloproteinase $^{5,6}$.

Penderita gangguan sendi temporomandibula ditandai dengan adanya keluhan nyeri pada pergerakan mandibula, pembukaan mulut terbatas, wajah asimetri dan adanya suara pada pergerakan sendi. Rasa nyeri pada rahang sering ditandai dengan gejala nyeri yang diiringi dengan telinga terasa tidak nyaman (stiffnes). Selain gejala dan keluhan seperti yang disebutkan di atas, masih ada gejala lain yang menyertai kelainan ini, yaitu rasa nyeri pada daerah kraniofasial yang melibatkan sendi temporomandibula, otot pengunyahan, kepala, leher, dan struktur muskuloskeletal. ${ }^{6}$ Penderita gangguan temporomandibula kadang-kadang tidak menyadari penyakit yang dideritanya, kalau ada keluhan biasanya diatasi sendiri. Apabila keluhan yang berat muncul dan mulai mengganggu aktivitas sehari-hari, baru mulai mencari pengobatan tapi biasanya tidak langsung ke tenaga medis yang tepat. Mereka biasanya ke tenaga medis lain dahulu, seperti spesialis THT, spesialis Syaraf atau tenaga medis lain, baru kemudian mendatangi Prostodontis. ${ }^{4}$

Gangguan sendi biasanya diawali dengan rasa tidak nyaman pada waktu mengunyah dan kemudian berlanjut pada kondisi yang sangat lelah saat menggerakan rahang dan akhirnya menimbulkan rasa nyeri pada waktu buka tutup mulut. Kondisi ini akan berlanjut bila tidak diatasi akan menimbulkan sakit kepala terus menerus ,menimbulkan kaku pada leher juga menimbulkan kondisi kekakuan pada otot bahu. Kondisi keteganggan otot merangsang rasa sensitif kalau dipalpasi menimbulkan rasa nyeri kondisi inilah yang disebut myfacial pain dan apabila berlanjut dengan pergerakan rahang dengan atau tanpa pembukaan mulut terbatas sudah mengarah ke kondisi disc displacement. Penelitian ini dilakukan untuk melihat perbedaan kadar IL-1 $\beta$ pada penderita myofascial pain dan disc displacement sendi temporomandibula

\section{BAHAN DAN METODE}

Penelitian ini dilakukan pada manusia dan bahan yang digunakan adalah saliva. Sebelum melakukan penelitian, dimintakan persetujuan etik kepada Panitia Etik Penelitian Fakultas Kedokteran Universitas Andalas. Penelitian ini merupakan penelitian observasional dengan disain cross-sectional comparative, yaitu variabel dependen dan independen diperiksa dalam waktu bersamaan.

Lokasi penelitian dilakukan di Poliklinik Prostodonsia Rumah Sakit Arifin Achmad Pekanbaru dan Laboratorium Biomedik Fakultas Kedokteran Universitas Andalas. Populasi penelitian adalah seluruh penderita gangguan sendi temporomandibular (STM) yang datang ke Poliklinik Prostodonsia RSUD Arifin Achmad Pekanbaru yang menderita myofascial pain dan disc displacement sendi temporomandibula.

Pengambilan sampel dilakukan secara consecutive sampling. Semua responden yang dijadikan sampel penelitian diperlakukan dengan prosedur yang sama mulai dari memberikan penjelasan sebelum persetujuan dan diikuti dengan penandatanganan informed consent. Kriteria sampel: Pria dan wanita dengan umur antara 17-50 tahun; mempunyai keluhan sesuai dengan diagnosis gangguan sendi temporomandibula yang ditegakkan oleh RDC-TMD Revisi 2010 Axis 1, 
yaitu myofascial pain dan disc displacement; oral mukosa oral sehat; tidak ada riwayat diabetes, hepatitis, penyakit ginjal, penyakit jantung, jamur pada rongga mulut; tidak menderita kelainan pada persendian (artritis) dan infeksi saluran pernafasan; tidak ada riwayat rawat inap dalam jangka waktu 6 bulan terakhir; tidak dalam perawatan ortodonti; tidak ada riwayat infertiliti atau hamil; dan bersedia menandatangani informed consent.

Pengambilan saliva dilakukan pada jam 09.0011.00 pagi sebanyak $5 \mathrm{ml}$ di Klinik Prostodontia RSUD Arifin Ahmad, Pekanbaru. Subjek dilarang minum atau makan yang mengandung kadar gula, asam, alkohol dan kafein 12 jam sebelum pengambilan sampel karena akan menurunkan $\mathrm{pH}$ saliva dan peningkatan pertumbuhan bakteri. Sebelum pengambilan saliva, subjek diminta puasa 2 jam kecuali minum air putih. Sikat gigi paling lambat 2 jam sebelum pengambilan saliva dengan cara tidak terlalu kuat.

Prosedur pengumpulan saliva dilakukan dengan cara: (1) Penderita yang didiagnosis myofascial pain atau disc displacement duduk di dental unit dengan posisi ergonomis: (2) Setelah mencatat status gangguan STM, seluruh sampel saliva dikumpulkan dari kedua kelompok; (3) Setiap subjek penelitian pertama kali diminta untuk berkumur dengan air suling untuk menghilangkan sisa-sisa makanan dan kemudian meludah ke dalam wadah plastik steril yang universal; (4) Lima menit setelah kumur-kumur, subjek diminta untuk meludahkan seluruh salivanya dengan cara menundukkan kepala ke bawah dan membiarkan air liur mengalir secara alami ke depan mulut. Subjek juga diminta tidak batuk. Subjek diminta untuk tidak berbicara; (5) Subjek menampung salivanya ke dalam tabung koleksi sekitar satu menit hingga 10 menit; (6) Saliva dikumpulkan dalam gelas steril $10 \mathrm{ml}$. Setelah terkumpul $5 \mathrm{ml}$, saliva ditempatkan dalam wadah plastik dan disimpan dalam refrigerator sebelum dipindahkan ke laboratorium untuk dianalisis dengan Elisa.

\section{HASIL}

Responden dengan gangguan sendi temporomandibula terdiri atas kelompok wanita, 57 orang dan kelompok laki-laki, 17 orang. Analisis statistik dengan Kolmogorov Smirnov pada kelompok wanita dan lakilaki yang menderita myofascial pain diperoleh nilai $p=0,772(p>0,05)$, yang berarti data terdistribusi normal. Berdasarkan klasifikasi umur didapat nilai rerata penderita disc displacement adalah 27,00 $\pm 9,32$ tahun dan myofascial pain adalah 30,32 $\pm 10,81$ tahun. Analisa statistik berdasarkan Kolmogorov Smirnov pada kelompok umur diperoleh nilai $p=1,000$ ( $p>$ 0,005 ) yang berarti data terdistribusi normal.
Pada kelompok laki-laki penderita myofascial pain, rerata kadar IL-1 $\beta$ saliva sebesar $7 \pm 9,32 \mathrm{~nm} / \mathrm{L}$ dan kelompok laki-laki penderita disc displacement sebesar $8 \pm 9,32 \mathrm{~nm} / \mathrm{L}$. Pada kelompok wanita penderita myofascial pain nilai rerata kadar IL-1 $\beta$ saliva sebesar $30 \pm 10,81 \mathrm{~nm} / \mathrm{L}$ dan kelompok wanita pada disc displacement kadar IL-1 $\beta$ sebesar $29 \pm 10,32 \mathrm{~nm} / \mathrm{L}$. Rerata nilai kadar IL-1 $\beta$ saliva untuk semua penderita dengan disc displacement sebesar 0,57 $\pm 0,45$ $\mathrm{nm} / \mathrm{L}$ dan penderita myofascial pain sebesar $0,22 \pm$ $0,18 \mathrm{~nm} / \mathrm{L}$. Hasil analisis data berdasarkan $t$ test terdapat perbedaan kadar IL-1 $\beta$ yang signifikan pada saliva antara penderita myofascial pain dan disc displacement sendi temporomandibula dengan nilai $p=0,00(p<0,05)$.

\section{PEMBAHASAN}

Umumnya wanita lebih banyak menderita sendi temporomandibular daripada laki-laki. Insidensi terjadinya gangguan sendi temporomandibula pada wanita lebih tinggi pada pria disebabkan oleh pengaruh tingkah laku, hormonal, anatomi dan psikososial. Berdasarkan kelompok umur tidak ada perbedaan signifikan insidens terjadinya disc displacement dan myofascial pain. 3,6,8,9

Berdasarkan hasil penelitian, kadar IL-1 $\beta$ saliva lebih tinggi pada disc displacement daripada myofascial pain signifikan, penderita dengan myofascial pain adalah tahapan awal gangguan sendi temporomandibula dengan manifestasi rasa sakit dan adanya sitokin inflamasi. Manifestasi sitokin inflamasi yang melibatkan TNF- $\alpha$ dan IL-1 $\beta$ yang menstimulasi netrofil dan menghasilkan PGE2. Ketika gangguan sendi temporomandibula meningkat keparahannya, kadar IL-1 $\beta$ meningkat sesuai dengan peningkatan gejala tahap lanjut dari myofascial pain yaitu disc displacement. ${ }^{1,4,6}$

Menurut Beuningen, peningkatan kadar IL-1 $\beta$ berkorelasi dengan tingkat keparahan gangguan sendi. Kadar sitokin yang tinggi berkorelasi dengan gejala gangguan sendi. Semakin parah gangguan sendi semakin tinggi kadar IL-1 $\beta$ terbukti dengan peningkatan kadar IL-1 $\beta$ yang terjadi pada disc displacement yang merupakan tahap lanjut myofascial pain. ${ }^{13}$

Peranan mediator kimiawi pada inflamasi seperti sitokin dengan adanya IL-1 $\beta$ dan TNF- $\alpha$ dengan neutrophin sebagai Nerve Growth Factor (NGF). Korelasi cairan sinovial dengan ekspresi IL-1 $\beta$, dengan berkurangnya cairan sinovial akan meningkatkan inflamasi yang disebabkan oleh gesekan akibat dari pergeseran diskus. Pada disc displacement terjadi gangguan lubrikasi dan nutrisi akibat gangguan biomekanis. $^{11}$ 
Eksudat pada gangguan sendi temporomandibula lanjut dihasilkan oleh serum mediator inflamasi akibat sel inflamasi kronis yang masuk ke rongga sendi. Sitokin mempunyai peranan penting pada gangguan sendi yang terlihat dalam cairan sinovial. ${ }^{6} \mathrm{Pe}-$ ranan IL-1 $\beta$ pada gangguan sendi temporomandibula tidak dapat diabaikan, semakin parah gangguan sendi temporomandibula semakin tinggi kadar IL$1 \beta$ yang akan bermanifestasi pada cairan sinovial,

\section{DAFTAR PUSTAKA}

1. Wadhwa S, Kapila S. TMJ disorders: future innovations in diagnostics and therapeutics. J Dent Educ 2008; 72(8): 730-47.

2. Luciana D. Prevalence of severity degrees temporomandibular joint disorder based on sex and age. Padjajaran J of Dentistry 2009. 21(1): 14-24

3. Slade GD, Diatchenko L, Maixner W. Orthodontic treatment, genetic factors and risk of temporomandibular disorder. J Semi Orthod 2012; 14(2): 146-56.

4. Laskin DM, Sener S, Akgunlu F. Sociodemographic comparison in patients with subjective and objective clinical findings of temporomandibular dysfunctions. Eur J Dent 2011; 5: 380-86.

5. Wheller A. Myofascial pain disorders: theory to therapy. Drug 2004; 64: 45-62.

6. Cairns DM, Uchimura T, Kwon T. Muscle cells enhance resistance to pro-inflammatory cytokine-induced cartilage destruction. Biochem Biophys Res Commun 2010; 392(1): 22-8.

7. Segal A, Wong TD, Salivary diagnostics: enhancing disease detection and making medicine better. Eur $\mathbf{J}$ Dent Educ 2008; 12: 22-9.

8. Mazzetto MO, Rodrigues CA, Magri LV, Melchior MO, Paiva G. Severity of TMD related to age, sex and electromyographic analysis. Braz Dent J 2014; 25(1): 54-8. darah atau saliva. Menurut Nascimento ${ }^{11}$ dan $\mathrm{Koh}^{12}$, kadar IL-1 $\beta$ sesuai dengan tingkat keparahan penyakit.

Terdapat nilai rerata kadar interleukin 1 beta saliva yang lebih tinggi pada penderita disc displacement dari pada myofascial pain sendi temporomandibula yang menunjukkan bahwa makin parah gangguan sendi makin tinggi kadar sitokin proinflamasi.

9. Blanco CA, Fernández CP, Isabel ALR, Galán FR, Svensson P. Characteristics of referred muscle pain to the head from active trigger points in women with myofascial temporomandibular pain and fibromyalgia syndrome. Headache Pain 2012; 13(8): 625-37.

10. Campos MIG, Campos PSF, Line SRF. Inflammatory cytokines activity in temporomandibular joint disorders: A review. Brazilian J Oral Scie 2006; 5(18): 1054-62.

11. Nascimento GC, Rizzi E, Gerlach RF, Paniss 1CR, Expression of MMP-2 and MMP-9 in the rat trigeminal ganglion during the development of temporomandibula joint inflammation. Braz J Med Biol Res 2013; 46(11): 956-67.

12. Koh KJ, Park HN, Kim KA. Relationship between anterior disc displacement with/without reduction and effusion in temporomandibular disorder patients using magnetic resonance imaging. Imaging Scie Dent 2013; 43(4): 245-51.

13. Beuningen HMV, Kraan PMVD, Arntz OJ, Den Berg WBV. Protection from Interleukin 1 induced destruction of articular cartilage by Transforming Growth Factor Beta: studies in anatomically intact cartilage in vitro and in vivo. Ann Rheum Dis Mar 1993; 52(3): 185-191 